\title{
Two "pillars" of cold-water coral reefs along Atlantic European margins: Prevalent association of Madrepora oculata with Lophelia pertusa, from reef to colony scale
}

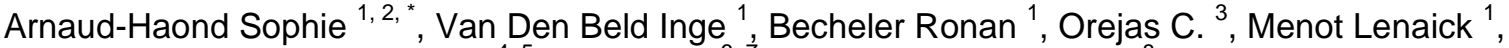 \\ Frank N. ${ }^{4,5}$, Grehan A. ${ }^{6,7}$, Bourillet Jean-Francois ${ }^{8}$
}

${ }^{1}$ Ifremer, Centre de Bretagne, Laboratoire Environnement Profond, CS 10070, 29280 Plouzané, France

${ }^{2}$ Ifremer, Station de Sète, Laboratoire Ressources Halieutiques de Sète, Avenue Jean Monnet - CS 30171, 34203 Sète Cedex, France

${ }^{3}$ Instituto Español de Oceanografía, Centro Oceanográfico de Baleares, Moll de Ponent s/n, 07015 Palma de Mallorca, Islas Baleares, Spain

${ }^{4}$ Institut für Umweltphysik, University Heidelberg, Im Neuenheimerfeld 229, 69120 Heidelberg, Germany

${ }^{5}$ Laboratoire des Sciences du Climat et de L'Environnement, unité mixte CEA-CNRS-UVSQ, Bât. 12 Avenue de la Terrasse, 91190 Gif-sur-Yvette, France

6,7 Earth and Ocean Sciences, School of NaturalSciences, National University of Ireland,Galway, Ireland, 2Ryan Institute, NationalUniversity of Ireland, Galway, Ireland

${ }^{8}$ Ifremer, Centre de Bretagne, Physical resources and sea floor ecosystems Department, CS 10070, 29280 Plouzané, France

* Corresponding author : Sophie Arnaud-Haond, email address : Sophie.Arnaud@ifremer.fr

\begin{abstract}
:
The scleractinian coral Lophelia pertusa has been the focus of deep-sea research since the recognition of the vast extent of coral reefs in North Atlantic waters two decades ago, long after their existence was mentioned by fishermen. These reefs where shown to provide habitat, concentrate biomass and act as feeding or nursery grounds for many species, including those targeted by commercial fisheries. Thus, the attention given to this cold-water coral (CWC) species from researchers and the wider public has increased. Consequently, new research programs triggered research to determine the full extent of the corals geographic distribution and ecological dynamics of "Lophelia reefs". The present study is based on a systematic standardised sampling design to analyse the distribution and coverage of CWC reefs along European margins from the Bay of Biscay to Iceland. Based on Remotely Operated Vehicle (ROV) image analysis, we report an almost systematic occurrence of Madrepora oculata in association with $L$. pertusa with similar abundances of both species within explored reefs, despite a tendency of increased abundance of $L$. pertusa compared to $M$. oculata toward higher latitudes. This systematic association occasionally reached the colony scale, with "twin" colonies of both species often observed growing next to each other when isolated structures were occurring off-reefs. Finally, several "false chimaera" were observed within reefs, confirming that colonial structures can be "coral bushes" formed by an accumulation of multiple colonies even at the inter-specific scale, with no need for self-recognition mechanisms. Thus, we underline the importance of the hitherto underexplored M. oculata in the Eastern
\end{abstract}


Atlantic, re-establishing a more balanced view that both species and their yet unknown interactions are required to better elucidate the ecology, dynamics and fate of European CWC reefs in a changing environment.

Keywords : Lophelia pertusa, Madrepora oculata, false-chimaera colonies, cold water corals (CWC), Bay of Biscay, Ireland, Iceland. 


\section{Introduction}

According to Jones' definition (Jones et al., 1994), corals are considered as autogenic engineers as they "change the environment via their own physical structures, i.e. their living and dead tissues". The population dynamics of these engineering species is determinant for the dynamics of the communities they support and the persistence of ecosystems they belong to.

Two main species of stony corals form reefs in the East Atlantic (Fig. 1), the scleractinians Lophelia pertusa (Linnaeus 1758) and Madrepora oculata (Linnaeus 1758). Historical reports of locations of coldwater coral (CWC) reefs date back to the 18th century in Norway (Gunnerus 1768) and early 20th century in Ireland and the Bay of Biscay (Joubin, 1922a, b; Le Danois, 1948) where massive formations were reported. In these reports, however, no distinction was made between L. pertusa and M. oculata, both refered to as "white corals". These reef-building "white corals" were opposed to the "yellow" corals that included species from the genus Dendrophyllia, such as D. cornigera (Lamarck 1816). Fisheries moving to deeper areas and seabed surveys motivated by prospecting for fossil energies (oil and gas) in the past two to three decades, have indeed led to the discovery of vast CWC reefs along continental margins (Rogers, 1999). The long-standing view that cold-water scleractinians would most often occur as isolated colonies at high latitudes, with occasional occurrence of dense formations, was then challenged by the discovery of the large Sula reef dominated by Lophelia pertusa on the mid-Norwegian shelf (Freiwald et al., 1999). Several reefs have been discovered and studied along European Atlantic margins in Norway and the Faroe Islands in the 90's (Frederiksen et al., 1992; Hovland et al., 1998; Hovland and Thomsen, 1997; Mortensen et al., 1995; Mortensen et al., 2001), followed by Ireland and the UK (Costello et al., 2005; De Mol et al., 2002; Roberts et al., 2003) and Sweden (Jonsson et al., 2004). Fosså et al. (2002) identified seven species of scleractinians occurring in Norwegian waters, of which only $L$. pertusa and $M$. oculata form reefs; these same authors also mentioned the lower abundance of $M$. oculata compared to L. pertusa, and that the former has never been reported to build reefs (Dons, 1944; 
Frederiksen et al., 1992). On a more recent quantitative study, Purser et al. (2013) also report a much lower abundance of M. oculata in the same waters. Possibly owing to the dominance of L. pertusa in the first explored reefs (Freiwald et al., 1999), this species remained the dominant focus of most subsequent cruises and ecological studies (Fig. 2) which target was often stated as "Lophelia reefs", whereas M. oculata remained comparatively rather neglected up to the mid 2000's (Fig. 2).

More recent expeditions and historical record compilations (Reveillaud et al., 2008) have shed more light on the southern European margins, highlighting the frequent occurrence and engineering role of $M$. oculata, at least in the Bay of Biscay and in the Western and Central Mediterranean (Gori et al., 2013; Orejas et al., 2009; Vertino et al., 2010) that were less studied than Northern reefs. However, due to the relatively recent consideration of this species and to the logistic difficulties inherent to deep-sea sampling and observation, no quantitative estimates exist, thus far, to appraise the compared geographical distribution of M. oculata and L. pertusa in the Northeastern Atlantic. Species structuring habitat, referred to as "structural" (Huston, 1994), "ecosystem engineers" (Jones et al., 1994), or "founder" species (Bruno and Bertness, 2001; Dayton, 1975), have a major role as driver of the prospects of ecosystems and associated communities under environmental fluctuations (Peterson et al., 1984). Identifying these habitat-forming species and defining their potential and realised ecological niche (Bruno et al., 2003) to better understand their role as a driver of community composition and dynamics is a prerequisite to most ecological studies including habitat modeling, the study of ecological interactions, the reconstruction of past history or the projection of future range shifts under environmental changes.

Here, we report on the observations made during two cruises taken place in 2011 and 2012, respectively, to locate reefs and appraise their extent in the Bay of Biscay, off Ireland and off south Iceland. We assessed the relative densities and seafloor area covered by both species in five sites sampled according to a standardised scheme (Becheler et al., this issue) using random sampling of transects and video 
analysis. Results provide the first estimates of the relative abundances of the two scleractinian species found in reefs identified along Atlantic European margins, supporting an equivalent importance of $M$. oculata and L. pertusa in terms of abundance and spatial extent.

\section{Material and Methods}

\subsection{Study sites}

During the BobEco cruise (September/October 2011), reefs from the Bay of Biscay and Celtic Sea were explored using the Remotely Operated Vehicle (ROV) Victor 6000 (Ifremer). The continental slope of the Bay of Biscay is regularly cut by a succession of submarine canyons connecting the continental shelf and the continental rise (Bourillet et al., 2003). In this area, CWC reefs formed by scleractinians were found to be typically located between 600 and $900 \mathrm{~m}$ depth, standing mostly above soft sediment. Five canyons were explored and sampled according to the procedure described in Becheler et al. (this issue), and standardised data were available for three of those canyons that are included in the present analysis (Le Croisic, Guilvinec and Petite-Sole; Fig. 3 \& Table 1).

The Logachev Mounds region on Rockall Bank, off West-Ireland, North Atlantic Ocean, was sampled during the same cruise (Fig. 3, Table 1). This area corresponds to multiple carbonate mounds colonised by CWCs, which are usually found at depths ranging from 500 to 1200 m (Mohn et al., 2014; van Haren et al., 2014). One dive was performed during the BobEco cruise in this area (Logachev, Fig. 3 \& Table 1). During the IceCTD cruise (June 2012), two reefs - Hafadjúp and Lonjúp - off South-Iceland in the North Atlantic, were also explored and sampled, of which one was analysed for this study (Hafadjúp, Fig. 3, Table 1).

\subsection{Sampling strategy}


In order to optimise the likelihood of locating living reefs, the targeted locations were defined using geomorphological criteria, including depth, slope, the position compared to basin catchment, sediment structure (Bourillet et al., 2012a), and unpublished observations of the seafloor from imagery analysis of dives made during previous cruises. The dives consisted of (1) exploration of the area and (2) sampling for taxonomy, barcoding and population genetic purposes. Sampling strategy relied on the definition of sampling quadrats of a standard size $(200 \mathrm{~m} * 100 \mathrm{~m})$ in continuous areas of each reef. These quadrats have been used for assessing the density (expressed as colonies per $\mathrm{m}^{2}$ ) and coverage (expressed as $\mathrm{m}^{2}$ ) of the two main reef building corals (see below).

Within the quadrats, one to three colonies of both L. pertusa and M. oculata were sampled on each of 35 randomly drawn GPS positions (Becheler et al., this issue), resulting in a total of approx. 500 samples across eight locations including the five reefs analysed in this study, of which the occurrence of "chimaera-like" (hetero-specific colonies) colonies was documented.

\subsection{Density and coverage estimates through video analysis}

During each sampling session, video frames from the quadrats were captured, and analysed for an assessment of the density and coverage of L. pertusa and M. oculata. Using randomly generated times, 20 frame-grabs ( $N=20$ ) were extracted from the downward-facing (vertically directed) camera (Fig. 4). Frame-grabs were excluded from analysis when they did not meet one or more of the following criteria: (i) the altitude of the ROV ranged between $0.8 \mathrm{~m}$ and $1.7 \mathrm{~m}$, (ii) the quality of the frame-grab was higher enough to allow an unambiguous visual distinction between L. pertusa and M. oculata colonies, and (iii) the surface of the seabed was perpendicular (or nearly so) to the vertical camera's axis to avoid distortion of pictures. During sampling, the ROV was positioned on the seabed for several minutes, allowing the possibility that two or more frame-grabs may capture the same area of seabed. In these 
instances only one of the frame-grabs have been included in the analysis, thus ensuring that an area, and therefore the same colonies, would not be recorded more than once.

A grid was used to calibrate images from the vertical camera. The calibration grid was a pattern of black and white squares of 0.7 by $0.7 \mathrm{~cm}$. The squares were measured on the image in pixel size and used as a scale to calculate the total surface of the seafloor visible on that image. In order to be conservative, calibration was done for a broad range of altitudes: between 0.5 and 5.0 meter with $0.5 \mathrm{~m}$ intervals, measured by an altimeter on the ROV. The total surfaces of the frame-grabs at these sequential altitudes were used as a scale to estimate the area covered by each analysed image and provided a quantitative measurement of coverage, e.g. in $\mathrm{m}^{2}$.

From each frame-grab the two scleractinian coral species L. pertusa and M. oculata were unambiguously identified using morphological criteria. Colonies were counted and the surface covered by them was measured to estimate (i) the density of live colonies of each species (colonies per square meter), (ii) the surface of live coral colonies (square meters covered by each species), (iii) the surface of dead coral framework and/or rubble (square meters covered by broken coral fragments), (iv) the surface of bare sediment, i.e. soft and/or hard substrate (square meters covered by the different substrate types) and (v) the surface of pebbles and cobbles (square meters covered by pebbles and cobbles). The free software program ImageJ (Schneider et al., 2012) was used to measure the seafloor surface occupied by the live colonies, the dead rubble/framework, the bare sediment and the pebbles/cobbles. ImageJ allows the user to select areas and measure them in either pixel size or in a pre-defined unit if a scale has been set. The contours of each of the previous mentioned structures were selected by hand in Image and the surface of these contours was calculated by the program in pixel size. In a later stage these surfaces in pixel sizes were converted to $\mathrm{m}^{2}$ calibrated using the total surface of the image calculated using the previous mentioned grid. Comparison of species density per $\mathrm{m}^{2}$ were performed through a Mann- 
Whitney test within each sampling location, as the data were not normally distributed and variances were not homogeneous.

\section{Results}

During exploration dives (to find reefs), isolated colonies of the two reef-building scleractinians were observed outside of reefs during prospective dives in all three regions. These colonies were extremely frequent (pers. obs.) and were often made of a compound of both species growing next to each other or interspersed, resulting in "twin colonies".

Additionally, when samples were sorted on deck, four "chimaera-like" colonies formed of fully merged branches of L. pertusa and M. oculata were observed in the Bay of Biscay and in Iceland (Fig. 1F, G). Approximately 500 colonies were collected across 8 reefs including the 5 studied here, suggesting a prevalence of less than $1 \%$ of these "chimaera-like" colonies. The careful dissection of the junction zone between branches of both species of one of the colonies revealed the existence of a systematic calcareous wall containing soft tissues and preventing their admixture (Arnaud-Haond, pers. obs.), supporting these compound colonies as "false-chimaeras".

Regardless of latitude, all explored locations where reefs were recorded and investigated supported both L. pertusa and M. oculata (Fig. $1 \mathrm{~A}$ to E). The large patchiness in the distribution of colonies within reefs leads to relatively low averaged density but large variance. Their respective coverage and densities were similar within each location (Fig. 5A and B), with no significant departure detected (Mann-Whitney p> 0.05) except for two locations in the Bay of Biscay where M. oculata showed larger seafloor coverage and a higher density of colonies per $\mathrm{m}^{2}$ than L. pertusa (Guilvinec, Coverage: $U=279 ; \mathrm{p}=0.033$ Density: $U=298 ; p=0.007 ;$ Petite Sole, Coverage: $U=322 ; p=0.001$ Density: $U=320 ; p=0.001$ ). For each species, the mean densities varied among locations, ranging from $0.02 \pm 0.11 \mathrm{col} . \mathrm{m}^{-2}$ (colonies per square meter), which would imply a single colony per $50 \mathrm{~m}^{2}$, to $1.41 \pm 1.61 \mathrm{col}$. $\mathrm{m}^{-2}$ for $L$. pertusa and from $0.12 \pm$ 
0.39 col. $\mathrm{m}^{-2}$ to $1.64 \pm 1.19$ col. $\mathrm{m}^{-2}$ for M. oculata (Table 1 ). In the Bay of Biscay, the mean seafloor coverage of $M$. oculata ranged between $0.010 \pm 0.01 \mathrm{~m}^{2}$ (colony surface per explored square meter) and $0.038 \pm 0.04 \mathrm{~m}^{2}$. The mean seafloor coverage of both Irish and Icelandic populations of $M$. oculata were in similar range, with mean coverage of $0.02 \pm 0.03 \mathrm{~m}^{2}$ and $0.01 \pm 0.03 \mathrm{~m}^{2}$ respectively (see Fig. $5 \mathrm{~B}$ and Table 1). This parameter is less variable for L. pertusa with mean values ranging from very small (only $0.0003 \pm 0.001 \mathrm{~m}^{2}$ in Petite-Sole) to $0.02 \pm 0.03 \mathrm{~m}^{2}$ in the Bay of Biscay. The L. pertusa population of Logachev Mounds (Ireland) showed larger seafloor coverage with a mean area of $0.03 \pm 0.05 \mathrm{~m}^{2}$, while the Icelandic colonies (Hafadjúp) showed slightly larger coverage than the minimum area range off France $\left(0.01 \pm 0.02 \mathrm{~m}^{2}\right.$; Fig. 5 and Table 1). An overall but not significant trend $(p=0.09)$ toward a relative decline of $M$. oculata was observed from Southernmost to Northernmost locations (Fig. 5C, D), with similar non-significant trends retrieved in terms of seafloor coverage (data not shown).

\section{Discussion}

Here we propose a re-appraisal of the relative importance of both reef-forming scleractinians $M$. oculata and L. pertusa along Northeastern Atlantic European margins, based on most recent exploration cruises and on standardised strategy allowing a formal comparison of data among sites. Within Northeast Atlantic CWC reefs spanning from the Bay of Biscay to Iceland, our results revealed a quasi-systematic co-occurrence of L. pertusa and M. oculata at nested scales: the region, reef, and also often at the colony scale through the frequent observation of twin colonies. These results suggest the expression "Lophelia reefs" is not appropriate and possibly misleading at least for this part of the geographical range of distribution of the two coral species. The clear literature bias toward L. pertusa (Fig. 2), thus far, is likely due to the history of the discovery of CWC reefs in the North-East Atlantic, with most pioneer studies investigating corals off Norway (Dons, 1944; Frederiksen et al., 1992; Freiwald et al., 1999; 
Hovland et al., 1998; Hovland and Thomsen, 1997; Rogers, 1999). Our study is based on a standardised strategy and analyses of ROV images to allow a formal comparison of data among sites and therefore encloses only data from transects located in the zone from central Bay of Biscay to Iceland, without data available for Norway or Sweden, which makes the comparison with these well-studied areas presently impossible. Data presented here show that along the western European margins, M. oculata is at least as important or even more, in terms of colony density and spatial coverage, than L. pertusa, with a trend toward decreasing occurrence in the northern-most location of this study off Iceland. These results, together with the dominance of $L$. pertusa along the Norwegian shelves (Fossa et al., 2002; Mortensen et al., 1995; Purser et al., 2013; Roberts et al., 2009; Rogers, 1999), and the dominance of M. oculata in the Mediterranean (Freiwald et al., 2009; Gori et al., 2013; Orejas et al., 2009; Taviani et al., 2005; Vertino et al., 2010) suggest an inverse South-North shift in the relative abundance of both reef-forming scleractinians (Fig. 5). Within the North-East Atlantic, this coexistence in comparable densities may indicate an overlapping of the ecological niches of both species. The data in Iceland are above all subjected to a large variance due to the high spatial heterogeneity in the distribution of large colonies forming Icelandic reefs, further data would, thus, be needed to formally test for the hypothesis of a general decline in M. oculata toward higher latitudes rather than just on Norwegian margins.

Whether this observation is reflecting a causal relationship with latitude induced, for example, by different changes of the environmental conditions due to rapid climate changes (Frank et al. 2011), or an influence of the peculiar seascape associated to CWC reefs encountered in the Bay of Biscay (sharp bathymetry and slopes in the canyons) cannot be disentangled. Recent studies showed clear physiological differences (growth rates, feeding ecology, metabolism, sensitivity to temperature and $\mathrm{pH}$ ) between the two species (Gori et al., 2014; Hennige et al., 2014b; Lartaud et al., 2013; Maier et al., 2012; Movilla et al., 2014; Naumann et al., 2014; Orejas et al., 2011). While most of these works were based on Mediterranean specimens, some of these results may indicate that L. pertusa is better adapted to lower 
temperatures, while M. oculata seems to exhibit a greater ability to grow in warmer waters (Naumann et al. 2014). Notably, the current temperature of the Mediterranean Sea is likely the maximum viable one for L. pertusa as referred by Freiwald et al. 2009. Laboratory experiments on Mediterranean specimens of the two coral species have also demonstrated a more efficient thermal acclimation to lower temperatures for L. pertusa than M. oculata within their natural thermal range (Naumann et al., 2014). Yet, most reefs identified and mapped during the BobEco cruise, as the ones reported here (Fig. 3) were located in areas characterised by specific geomorphological conditions including rather steep slopes (10 to $40^{\circ}$ ), associated with the canyon flanks (Bourillet et al., 2012b). As a matter of fact, when explored areas (during BobEco, or the previous BobGeo and Evhoe cruises) exhibited flat or almost flat seascapes, some in the close vicinity of approximate locations initially reported by Joubin (1922) and le Danois (1948) as supporting extensive density of corals damaging trawling nets, no scleractinian masses were observed. At best isolated colonies could be recorded, that were often "twin" colonies of both species growing in the next to each other off-reef (Arnaud-Haond, pers. Obs.). In the Mediterranean, where CWC are mostly observed on cliffs in canyons, mounds and escarpments, M. oculata is largely dominant (up to 50 times more abundant in Cap de Creus or Lacaze-Duthiers canyons, Gulf of Lion) over L. pertusa (Gori et al., 2013; Orejas et al., 2009). Madrepora oculata formations (being the species dominant over $L$. pertusa) have also been found in the Santa Maria di Leuca province (and other locations in the Ionian Sea), that show a rough seafloor topography, including ridges and scarps (Vertino et al., 2010). Contrastingly, in Ireland and Iceland much flatter areas characterised the locations where reefs were observed and studied. The relative importance (maximal densities) and patchiness (degree of aggregation) of M. oculata in our study may, thus, either be influenced by latitudinal gradients, or by some local differences in seascape such as slope steepness and availability of hard substrate (Orejas et al., 2009) or hydrodynamic currents controlled by the local bathymetry (Khripounoff et al., 2014). Additionally, life history differences between both species may lead to hypothesise a more " $r$ " strategy 
for M. oculata, with a larval dispersal and settlement requirement promoting rapid colonisation of newly available grounds and higher prevalence in less stable areas. Further data would be needed to explore those alternative drivers of the admixture of structural species forming CWC reefs in the North-East Atlantic. Nevertheless, paleo-geographical records of CWC reefs in Mediterranean (Taviani et al., 2005) and Gulf of Cadiz (Wienberg et al., 2009) clearly suggest that M. oculata better tolerates environmental fluctuations than L. pertusa and the progressive warming of the Mediterranean after the end of the Last Glacial Maximum (LGM, 11000 y.BP) affected the relative abundances of both species toward a dominance of M. oculata. For the Bay of Biscay, important changes in sea water temperature and sediment supply occurred just at the end of the LGM (between ca. 20 and $17 \mathrm{ka}$ ). A large discharge of meltwater due to the decay of the British and Fennoscandian ice-sheets arrived on the shelf and slope from the Fleuve Manche paleoriver (Toucanne et al., 2012; Toucanne et al., 2010), and a subsequent sediment discharge was delivered to the slope into the canyons between 17 and 8 ka (Toucanne et al., 2012). These facts, together with the recent results from eco-physiological studies (Gori et al., 2014; Hennige et al., 2014b; Lartaud et al., 2013; Maier et al., 2012; Movilla et al., 2014; Naumann et al., 2014; Orejas et al., 2011) and present data, indicate that the temperature range may, thus, be an important factor discriminating the distribution range and potential niches of both species that would, therefore, partially overlap. Additionally, M. oculata, appears more dominant in apparently heavily impacted areas where smaller reefs were observed in terms of height, and where most fishing gears and trawling marks were detected (Croisic and Guilvinec in particular; Van den Beld et al., this issue). This might be related due to different life-history traits of M. oculata compared to L. pertusa, including a faster growth (Orejas et al., 2011), or a possible quicker settlement after perturbations (differences in gametogenesis for example, or size of oocytes or larvae, ...), and may deserve further attention. 
Colonies can be defined as structures attached to the substratum at one point (Stoddart and Johannes, 1978) and growing vertically by asexual reproduction of individual polyps, thus forming "ramets" (Harper, 1977; Hughes, 1989) such as all colonies grown from one larvae issued from a single event of sexual reproduction are belonging to the same clonal lineage (also called "genet"). The "false chimaeras" formed by a M. oculata and L. pertusa colony, one settled on the other, demonstrate the admixed nature of these structures that may better be considered as "coral bushes" (Wilson, 1979) composed of different genets settled on each other and intermingling through time (Fig. 1F, G). These observations thus reveal the common juxtaposition of multiple genets, due to the settlement of larvae on an implanted colony, rather than real chimaeras or hybrid colonies. First, in the absence of fusion of soft tissue or evidence of coenosarc structure bridging heterospecific polyps, this observations shows that self-recognition that was recently suggested in the case of "chimaera-like" colonies of L. pertusa (Hennige et al., 2014a) is not required to explain these formations. This may rather suggest that the calcareous skeleton of scleractinian corals can be considered as a substrate type that could facilitate settling and development of particles. However, observations made in the Bay of Biscay, Ireland (Logatchev mounds) and Iceland (Hafadjúp) also point toward an almost systematic occurrence of both species in the explored locations, including areas where only isolated bushes were recorded often exhibiting an admixture of both species either 'merged' (Fig. 1F, G) or settled next to each other (Fig. 1A to E). This suggests not only a strong overlap of their realised niche in the Bay of Biscay and Logatchev mounds, and to a lower extent in Hafadjúp, but also a possible positive interaction between species, i.e. the presence of one potentially facilitating the other (Bruno and Bertness, 2001; Bruno et al., 2003) that may be explored both experimentally and through habitat modeling in the Bay of Biscay. This colony juxtaposition brings back the term from Pérès and Piccard (1964) to the present times that was used to describe these coral communities in the Mediterranean, where they reported no named species 
dominance, i.e. "le biocenose des coraux blancs" ("biocenosis of white coral"), which following given our observations may be very appropriate.

As paleontological records show different responses to past climatic oscillations for both species, their distribution in the northeastern Atlantic may therefore evolve differently under future environmental changes depending on their interaction in their potential and realised niches (Bruno et al., 2003; McGill et al., 2006). As a result, the comprehensive reconstitution of the influence of past climate changes on the biogeographic history of CWC reefs based on geochronological and genetic studies has to encompass both species. However, whereas isotopic studies performed thus far often included M. oculata (Frank et al., 2004; Frank et al., 2009; McCulloch et al., 2010; Montero-Serrano et al., 2013), no genetic studies thus far have concomitantly tackled the present day or past connectivity of $M$. oculata with that of $L$. pertusa. Similarly, there is a need to enhance knowledge of habitat suitability and sensitivity to environmental changes (Rengstorf et al., 2013) of M. oculata, as the occurrence of species communities supported by CWC reefs nowadays may depend on the persistence of both in part of their distribution ranges, or only one of the two habitat forming species.

Conclusion:

In conclusion, CWC reefs along European margins are reliant on two pillars of scleractinian species, namely $L$. pertusa and $M$. oculata, as opposed to the current held misconceived view that only the former species provides vast structural habitats for a diverse community of associated species. The prevalence of the $M$. oculata being more important than considered to date, particularly at lower latitudes, the designation of "Lophelia reefs" may thus not be adapted to most reefs along eastern Atlantic margins. These results suggest a complete overlap of realised niches in the Bay of Biscay with a possible divergence biased toward M. oculata in the Mediterranean and L. pertusa at higher latitudes, or 
at least in northeastern locations; resulting in an inverse gradient of density for both species with an increase of $M$. oculata and a decrease of L. pertusa from North to South. Altogether with a quasisystematic occurrence of both species in the canyons of the Bay of Biscay, these observations call for further research to understand both the width and overlap of potential and realised niches for both species, and the way their interaction may lead to possible facilitation in some geographic areas. Finally, the observations of "false chimaera" from the Bay of Biscay to Iceland, despite a rather low sampling density, reveals the ability of larvae to settle on already established colony, an event that may occur as often or more among conspecifics without necessarily requiring self-recognition of colonies. The latter observation provides evidence that intra- (and inter-) specific diversity can be expected at the scale of what could, thus, be described as "coral bushes" formed by multiple homo- or heterospecific colonies growing interspersed.

Acknowledgments

This work was performed in the framework of the EC FP7 project 'CoralFISH' under grant agreement no. 213144.We would like to thank the captains and crew of the R/V Pourquoi Pas? (BobEco cruise 2011) and the R/V Le Thalassa (Ice-CTD cruise 2012) as well as all participants who directly or indirectly contributed to the data acquisition. We wish to thank Stefán Ragnarsson for his invaluable help for planning dive plans in Iceland during IceCTD, Jaime Davies for her comments on the manuscript, as well as the Editor Chris Yesson and two anonymous referees for useful comments on a previous version of this manuscript. 


\section{References}

Bourillet, J.-F., de Chambure, L., Loubrieu, B., 2012a. Sur les traces des coraux d'eau froide du golfe de Gascogne. 8 cartes bathymorphologiques et géomorphologiques au 1/100.000, in: (Ed.)., I.Q. (Ed.).

Bourillet, J.-F., de Chambure, L., Loubrieu, B., Arnaud-Haond, S., Guillaumont, B., Veslin, M., BobGeo_BobEco_scientific_teams, a., 2012b. Geomorphology of the Bay of Biscay and cold-water corals habitat mapping (NE Atlantic)., in: Ecosystem based management and monitoring in the deep Mediterranean \& N. Atlantic (Ed.), Deepfishman \& Coralfish meeting, August 28-31 2012, Galway, Ireland.

Bourillet, J.-F., Reynaud, J.-Y., Baltzer, A., Zaragosi, S., 2003. The "Fleuve Manche": the sub-marine sedimentary features from the outer shelf to the deep-sea fans. J Quaternary Sci 18, 261-282.

Bruno, J.F., Bertness, M.D., 2001. Habitat modification and facilitation in benthic marine communities. Marine community ecology, 201-218.

Bruno, J.F., Stachowicz, J.J., Bertness, M.D., 2003. Inclusion of facilitation into ecological theory. Trends in Ecology \& Evolution 18, 119-125.

Costello, M.J., McCrea, M., Freiwald, A., Lundalv, T., Jonsson, L., Bett, B.J., van Weering, T.C.E., de Haas, H., Roberts, J.M., Allen, D., 2005. Role of cold-water Lophelia pertusa coral reefs as fish habitat in the NE Atlantic.

Dayton, P.K., 1975. Experimental Evaluation of Ecological Dominance in a Rocky Intertidal Algal Community. Ecological Monographs 45, 137-159.

De Mol, B., Van Rensbergen, P., Pillen, S., Van Herreweghe, K., Van Rooij, D., McDonnell, A., Huvenne, V., Ivanov, M., Swennen, R., Henriet, J.P., 2002. Large deep-water coral banks in the Porcupine Basin, southwest of Ireland. Marine Geology 188, 193-231.

Dons, C., 1944. Norges korallrev. K norske Vidensk Selsk Forh 16, 37-82.

Fossa, J.H., Mortensen, P.B., Furevik, D.M., 2002. The deep-water coral Lophelia pertusa in Norwegian waters: distribution and fishery impacts. Hydrobiologia 471, 1-12.

Frank, N., Paterne, M., Ayliffe, L., van Weering, T., Henriet, J.P., Blamart, D., 2004. Eastern North Atlantic deep-sea corals: tracing upper intermediate water Delta C-14 during the Holocene. Earth and Planetary Science Letters 219, 297-309.

Frank, N., Ricard, E., Lutringer-Paquet, A., van der Land, C., Colin, C., Blamart, D., Foubert, A., Van Rooij, D., Henriet, J.-P., de Haas, H., van Weering, T., 2009. The Holocene occurrence of cold water corals in the NE Atlantic: Implications for coral carbonate mound evolution. Marine Geology 266, 129-142. 
Frederiksen, R., Jensen, A., Westerberg, H., 1992. The distribution of the scleractinian coral Lophelia pertusa around the faroe islands and the relation to internal tidal mixing. Sarsia 77, 157-171.

Freiwald, A., Beuck, L., Rueggeberg, A., Taviani, M., Hebbeln, D., 2009. The white coral community in the Central Mediterranean Sea Revealed by ROV Surveys. Oceanography 22, 58-74.

Freiwald, A., Wilson, J.B., Henrich, R., 1999. Grounding Pleistocene icebergs shape recent deep-water coral reefs. Sedimentary Geology 125, 1-8.

Gori, A., Grover, R., Orejas, C., Sikorski, S., Ferrier-Pages, C., 2014. Uptake of dissolved free amino acids by four cold-water coral species from the Mediterranean Sea. Deep-Sea Research Part li-Topical Studies in Oceanography 99, 42-50.

Gori, A., Orejas, C., Madurell, T., Bramanti, L., Martins, M., Quintanilla, E., Marti-Puig, P., Lo lacono, C., Puig, P., Requena, S., Greenacre, M., Gili, J.M., 2013. Bathymetrical distribution and size structure of cold-water coral populations in the Cap de Creus and Lacaze-Duthiers canyons (northwestern Mediterranean). Biogeosciences 10, 2049-2060.

Harper, J.L., 1977. Population Biology of Plants.

Hennige, S.J., Morrison, C.L., Form, A.U., Büscher, J., Kamenos, N.A., Roberts, J.M., 2014a. Selfrecognition in corals facilitates deep-sea habitat engineering. Sci. Rep. 4.

Hennige, S.J., Wicks, L.C., Kamenos, N.A., Bakker, D.C.E., Findlay, H.S., Dumousseaud, C., Roberts, J.M., 2014b. Short-term metabolic and growth responses of the cold-water coral Lophelia pertusa to ocean acidification. Deep-Sea Research Part li-Topical Studies in Oceanography 99, 27-35.

Hovland, M., Mortensen, P.B., Brattegard, T., Strass, P., Rokoengen, K., 1998. Ahermatypic coral banks off Mid-Norway: Evidence for a link with seepage of light hydrocarbons. Palaios 13, 189-200.

Hovland, M., Thomsen, E., 1997. Cold-water corals - Are they hydrocarbon seep related? Marine Geology 137, 159-164.

Hughes, R., 1989. Functional biology of clonal animals.

Huston, M.A., 1994. Biological diversity: The coexistence of species on changing landscapes, Cambridge. Jones, C.G., Lawton, J.H., Shachak, M., 1994. Organisms as ecosystem engineers. Oikos 69, 373-386.

Jonsson, L.G., Nilsson, P.G., Floruta, F., Lundalv, T., 2004. Distributional patterns of macro- and megafauna associated with a reef of the cold-water coral Lophelia pertusa on the Swedish west coast. Marine Ecology Progress Series 284, 163-171.

Joubin, L., 1922a. Distribution géographique de quelques coraux abyssaux dans les mers occidentales européennes. Comptes Rendus de l'Académie des Sciences 175, 930-933. 
Joubin, L., 1922b. Les coraux de mer profonde nuisibles aux chalutiers. Notes et Mémoires, in: Maritimes, O.S.T.P. (Ed.), pp. 5-16.

Lartaud, F., Pareige, S., de Rafelis, M., Peuillassier, L., Bideau, M., Peru, E., Romans, P., Alcala, F., Le Bris, N., 2013. A new approach for assessing cold-water coral growth in situ using fluorescent calcein staining. Aquatic Living Resources 26, 187-196.

Le Danois, E., 1948. Les profondeurs de la mer. Trente ans de recherche sur la faune sous-marine au large des côtes de France, Paris.

Maier, C., Watremez, P., Taviani, M., Weinbauer, M.G., Gattuso, J.P., 2012. Calcification rates and the effect of ocean acidification on Mediterranean cold-water corals. Proceedings of the Royal Society BBiological Sciences 279, 1716-1723.

McCulloch, M., Taviani, M., Montagna, P., Lopez Correa, M., Remia, A., Mortimer, G., 2010. Proliferation and demise of deep-sea corals in the Mediterranean during the Younger Dryas. Earth and Planetary Science Letters 298, 143-152.

McGill, B.J., Enquist, B.J., Weiher, E., Westoby, M., 2006. Rebuilding community ecology from functional traits. Trends Ecol Evol 21, 178-185.

Mohn, C., Rengstorf, A., White, M., Duineveld, G., Mienis, F., Soetaert, K., Grehan, A., 2014. Linking benthic hydrodynamics and cold-water coral occurrences: A high-resolution model study at three coldwater coral provinces in the NE Atlantic. Prog Oceanogr 122, 92-104.

Montero-Serrano, J.-C., Frank, N., Tisnerat-Laborde, N., Colin, C., Wu, C.-C., Lin, K., Shen, C.-C., Copard, K., Orejas, C., Gori, A., De Mol, L., Van Rooij, D., Reverdin, G., Douville, E., 2013. Decadal changes in the mid-depth water mass dynamic of the Northeastern Atlantic margin (Bay of Biscay). Earth and Planetary Science Letters 364, 134-144.

Mortensen, P.B., Hovland, M., Brattegard, T., Farestveit, R., 1995. Deep water bioherms of the scleractinian coral Lophelia pertusa (L.) at $64^{\circ} \mathrm{N}$ on the Norwegian shelf: structure and associated megafauna. Sarsia 80, 145-158.

Mortensen, P.B., Hovland, M.T., Fossa, J.H., Furevik, D.M., 2001. Distribution, abundance and size of Lophelia pertusa coral reefs in mid-Norway in relation to seabed characteristics. Journal of the Marine Biological Association of the United Kingdom 81, 581-597.

Movilla, J., Gori, A., Calvo, E., Orejas, C., Lopez-Sanz, A., Dominguez-Carrio, C., Grinyo, J., Pelejero, C., 2014. Resistance of Two Mediterranean Cold-Water Coral Species to Low-pH Conditions. Water-Sui 6, 59-67. 
Naumann, M.S., Orejas, C., Ferrier-Pages, C., 2014. Species-specific physiological response by the coldwater corals Lophelia pertusa and Madrepora oculata to variations within their natural temperature range. Deep-Sea Research Part li-Topical Studies in Oceanography 99, 36-41.

Orejas, C., Ferrier-Pages, C., Reynaud, S., Gori, A., Beraud, E., Tsounis, G., Allemand, D., Gili, J.M., 2011. Long-term growth rates of four Mediterranean cold-water coral species maintained in aquaria. Mar Ecol Prog Ser 429, 57-65.

Orejas, C., Gori, A., Lo lacono, C., Puig, P., Gili, J.M., Dale, M.R.T., 2009. Cold-water corals in the Cap de Creus canyon, northwestern Mediterranean: spatial distribution, density and anthropogenic impact. Mar Ecol Prog Ser 397, 37-51.

Pérès, J.M., Piccard, J., 1964. Nouveau manuel de bionomie benthique de la mer Mediterranée. Extrait du recueil des travaux de la station marine d'Endoume Bulletin 31, 1-137.

Peterson, C.H., Summerson, H.C., Duncan, P.B., 1984. The influence of seagrass cover on population structure and individual growth rate of a suspension-feeding bivalve, $<i$ xmlns="http://pub2web.metastore.ingenta.com/ns/">Mercenaria mercenaria</i>. Journal of Marine Research 42, 123-138.

Purser, A., Orejas, C., Gori, A., Tong, R., Unnithan, V., Thomsen, L., 2013. Local variation in the distribution of benthic megafauna species associated with cold-water coral reefs on the Norwegian margin. Continental Shelf Research 54, 37-51.

Rengstorf, A.M., Yesson, C., Brown, C., Grehan, A.J., 2013. High-resolution habitat suitability modelling can improve conservation of vulnerable marine ecosystems in the deep sea. Journal of Biogeography 40, $1702-1714$.

Reveillaud, J., Freiwald, A., Van Rooij, D., Le Guilloux, E., Altuna, A., Foubert, A., Vanreusel, A., Roy, K.O.L., Henriet, J.-P., 2008. The distribution of scleractinian corals in the Bay of Biscay, NE Atlantic. Facies 54, 317-331.

Roberts, J.M., Davies, A.J., Henry, L.A., Dodds, L.A., Duineveld, G.C.A., Lavaleye, M.S.S., Maier, C., van Soest, R.W.M., Bergman, M.J.N., Huehnerbach, V., Huvenne, V.A.I., Sinclair, D.J., Watmough, T., Long, D., Green, S.L., van Haren, H., 2009. Mingulay reef complex: an interdisciplinary study of cold-water coral habitat, hydrography and biodiversity. Marine Ecology Progress Series 397, 139-151.

Roberts, J.M., Long, D., Wilson, J.B., Mortensen, P.B., Gage, J.D., 2003. The cold-water coral Lophelia pertusa (Scleractinia) and enigmatic seabed mounds along the north-east Atlantic margin: are they related? Marine Pollution Bulletin 46, 7-20. 
Rogers, A.D., 1999. The biology of Lophelia pertusa (LINNAEUS 1758) and other deep-water reef-forming corals and impacts from human activities. Int. Rev. Hydrobiol. 84, 315-406.

Schneider, C.A., Rasband, W.S., Eliceiri, K.W., 2012. NIH Image to ImageJ: 25 years of image analysis. Nature Methods 9, 671-675.

Stoddart, D.R., Johannes, R.E., 1978. Coral reefs: Research methods., in: Methodol., M.O. (Ed.). UNESCO, Paris. $x v$, p. 581pp.

Taviani, M., Remia, A., Corselli, C., Freiwald, A., Malinverno, E., Mastrototaro, F., Savini, A., Tursi, A., 2005. First geo-marine survey of living cold-water Lophelia reefs in the Ionian Sea (Mediterranean basin). Facies 50, 409-417.

Toucanne, S., Zaragosi, S., Bourillet, J.-F., Dennielou, B., Jorry, S.J., Jouet, G., Cremer, M., 2012. External controls on turbidite sedimentation on the glacially-influenced Armorican margin (Bay of Biscay, western European margin). Marine Geology 303-306, 137-153.

Toucanne, S., Zaragosi, S., Bourillet, J.-F., Marieu, M., Cremer, M., Kageyama, M., Van Vliet Lanoe, B., Eynaud, F., Turon, J.L., Gibbard, P., 2010. The first estimation of Fleuve Manche palaeoriver discharge during the last deglaciation: evidence for Fennoscandian ice sheet meltwater flow through the English Channel ca 20-18 ka ago. Earth Planet Sc Lett 290, 459-473.

van Haren, H., Mienis, F., Duineveld, G.C.A., Lavaleye, M.S.S., 2014. High-resolution temperature observations of a trapped nonlinear diurnal tide influencing cold-water corals on the Logachev mounds. Prog Oceanogr 125, 16-25.

Vertino, A., Savini, A., Rosso, A., Di Geronimo, I., Mastrototaro, F., Sanfilippo, R., Gay, G., Etiope, G., 2010. Benthic habitat characterization and distribution from two representative sites of the deep-water SML Coral Province (Mediterranean). Deep-Sea Research Part li-Topical Studies in Oceanography 57, 380-396.

Wienberg, C., Hebbeln, D., Fink, H.G., Mienis, F., Dorschel, B., Vertino, A., Lopez Correa, M., Freiwald, A., 2009. Scleractinian cold-water corals in the Gulf of Cadiz-First clues about their spatial and temporal distribution. Deep-Sea Research Part I-Oceanographic Research Papers 56, 1873-1893.

Wilson, J.B., 1979. Patch Development of the Deep-Water Coral Lophelia-Pertusa (L) on Rockall Bank. Journal of the Marine Biological Association of the United Kingdom 59, 165-\&. 
Fig. 1: $A-E$ ) reefs showing the intermingling of both species (white arrow shows a Lophelia pertusa colony, yellow arrow a Madrepora oculata colony) in the Croisic (A), Guilvinec (B) and Petite Sole (C) canyons in the Bay of Biscay, at the Logachev Mounds region in Ireland (D) and at Hafadjúp off Iceland (E); F-G) "chimaera"-like colony (white arrow shows a Lophelia polyp, yellow arrow a Madrepora polyp) sampled in the Bay of Biscay (F) and off Iceland (G).

Fig. 2: Temporal evolution (cumulative) of the number of studies recorded in the Web of Science mentioning Lophelia pertusa (plain line) or Madrepora oculata (dot line) in the topic (including title, abstract and keywords).

Fig. 3: Map of studied reefs (from South to North; Crs: Croisic, Glv: Guilvinec, Psl: Petite Sole, Log: Logachev Mounds, Haf: Hafadjúp). Projection is WGS 1984 World Mercator.

Fig. 4: An example of the method used to measure the coverage of the live colonies of L. pertusa and $M$. oculata. A) The calibration grid used to calculate the total surface of a frame-grab, B) an example of a frame-grab of the vertical camera of the ROV and C) an example of a treated frame-grab from the Logachev Mounds region, Ireland, with ImageJ, including the contours of 4 live colonies.

Fig. 5: boxplots showing the A) density of and B) surface covered by Madrepora oculata (grey) and Lophelia pertusa (white) in standardized quadrats analyzed for 5 locations (Bob = Bay of Biscay), with significant differences indicated by stars, and the evolution of the relative $C$ ) densities (no significant relationships, $R=0.54 p=0.15$ for $M$. oculata, $R=0.00 p=0.91$ for $L$. pertusa) and $D$ ) proportions of both species when driving from southernmost canyon of Le Croisic in the Bay of Biscay to the northernmost reef of Hafadjúp off Iceland. No significant regressions were associated to the two last analysis $(R=0.66$; $p=0.09)$. 
Table 1: Details of the regions and locations (with approximate depth) in which reefs were observed, including mean densities and the average surface areas covered (and standard deviation) of M. oculata and L. pertusa. Data correspond to 20 frame-grabs for each of 3 canyons in the Bay of Biscay, the Logachev Mounds region off Ireland and for Hafadjúp off Iceland. Significant differences in density and coverage documented for both species are indicated by bold values $(p<0.05)$.

\begin{tabular}{|c|c|c|c|c|c|c|}
\hline \multirow[t]{2}{*}{ Location (depth) } & \multirow{2}{*}{\multicolumn{2}{|c|}{ GPS coordinates }} & \multicolumn{2}{|c|}{ Madrepora oculata } & \multicolumn{2}{|l|}{ Lophelia pertusa } \\
\hline & & & $\begin{array}{l}\text { Colony density } \\
\text { (Colonies per } \\
\mathrm{m}^{2} \text { ) }\end{array}$ & $\begin{array}{l}\text { Coral } \\
\text { coverage } \\
\left(\mathrm{m}^{2}\right)\end{array}$ & $\begin{array}{l}\text { Colony density } \\
\text { (Colonies per } \\
\mathrm{m}^{2} \text { ) }\end{array}$ & $\begin{array}{l}\text { Coral } \\
\text { coverage } \\
\left(\mathrm{m}^{2}\right)\end{array}$ \\
\hline \multicolumn{7}{|l|}{ Bay of Biscay } \\
\hline Croisic (850m) & $46^{\circ} 23^{\prime} 000 \mathrm{~N}$ & $4^{\circ} 41^{\prime} 000 \mathrm{~W}$ & $1.30 \pm 1.42$ & $0.02 \pm 0.03$ & $0.62 \pm 0.76$ & $0.01 \pm 0.01$ \\
\hline Guilvinec $(850 \mathrm{~m})$ & $46^{\circ} 56^{\prime} 043 \mathrm{~N}$ & $5^{\circ} 36^{\prime} 0599 \mathrm{~W}$ & $1.64 \pm 1.19$ & $0.04 \pm 0.04$ & $0.69 \pm 0.90$ & $0.02 \pm 0.03$ \\
\hline Petite Sole $(650 \mathrm{~m})$ & $48^{\circ} 07^{\prime} 320 \mathrm{~N}$ & $8^{\circ} 48^{\prime} 800 \mathrm{~W}$ & $0.53 \pm 0.61$ & $0.01 \pm 0.02$ & $0.02 \pm 0.11$ & $0.00 \pm 0.00$ \\
\hline Ireland (800m) & $55^{\circ} 31^{\prime} 370 \mathrm{~N}$ & $15^{\circ} 38^{\prime} 900 \mathrm{~W}$ & $1.04 \pm 0.80$ & $0.02 \pm 0.02$ & $1.41 \pm 1.61$ & $0.03 \pm 0.05$ \\
\hline Iceland (400m) & $63^{\circ} 20^{\prime} 430 \mathrm{~N}$ & $19^{\circ} 35^{\prime} 800 \mathrm{~W}$ & $0.12 \pm 0.39$ & $0.01 \pm 0.03$ & $0.26 \pm 0.35$ & $0.01 \pm 0.02$ \\
\hline
\end{tabular}




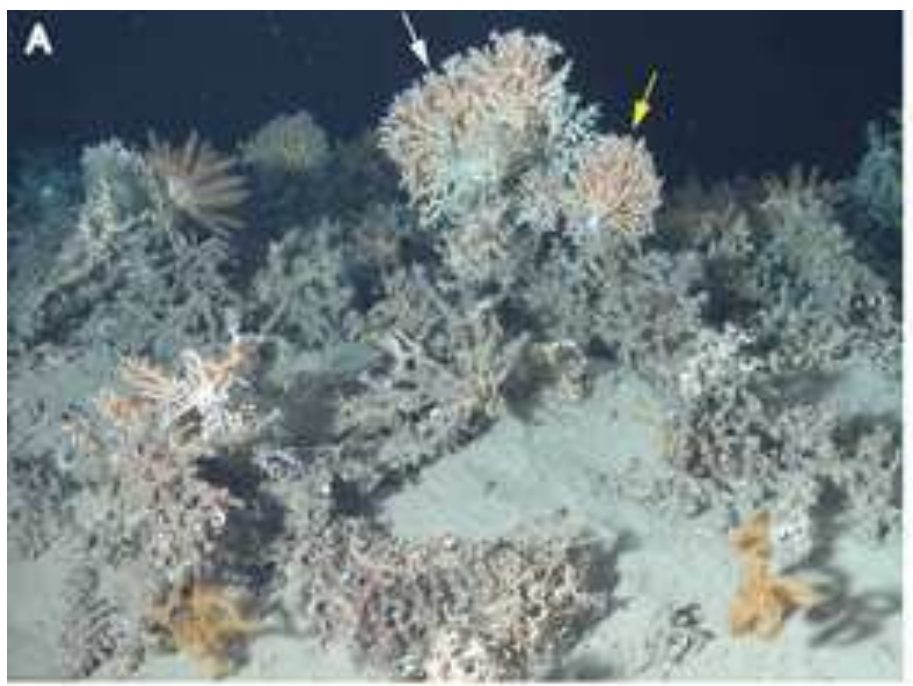

B

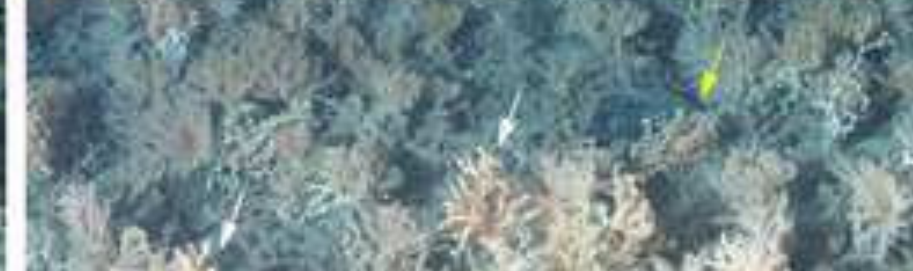

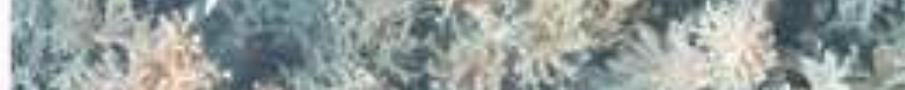

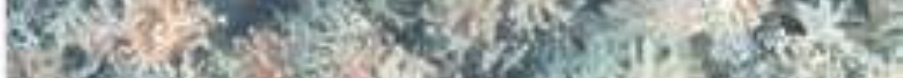

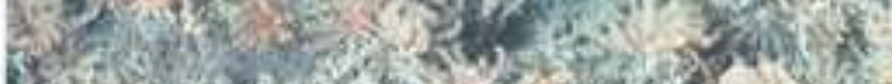

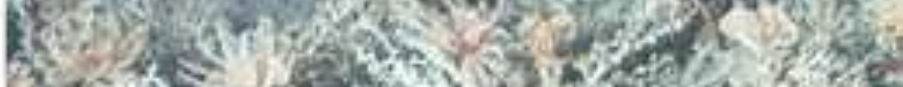

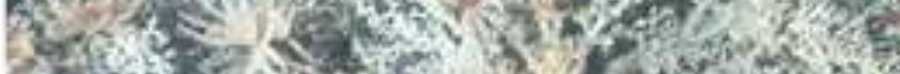

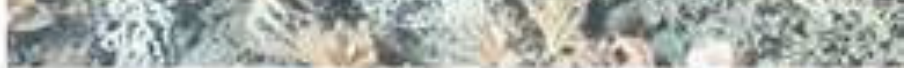
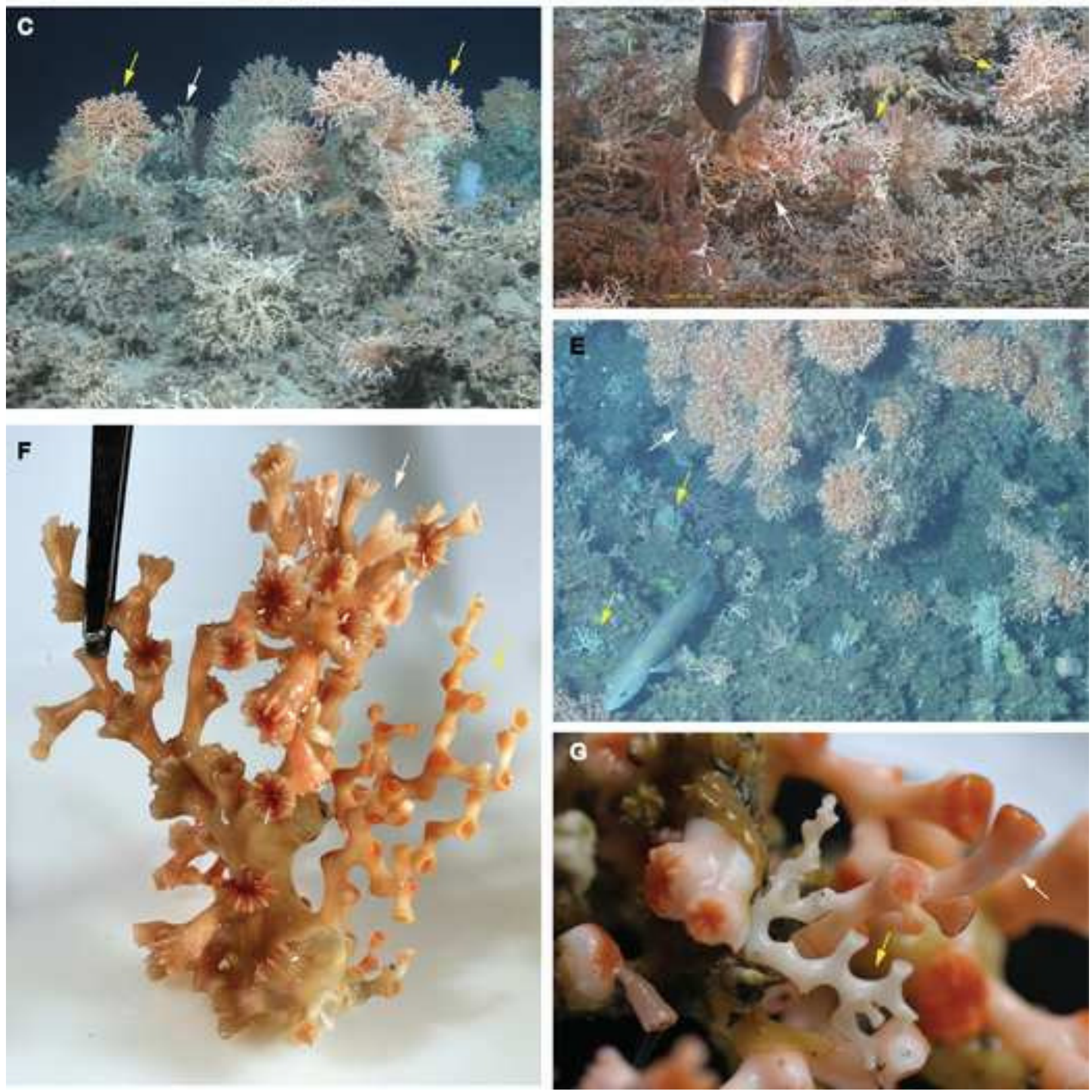


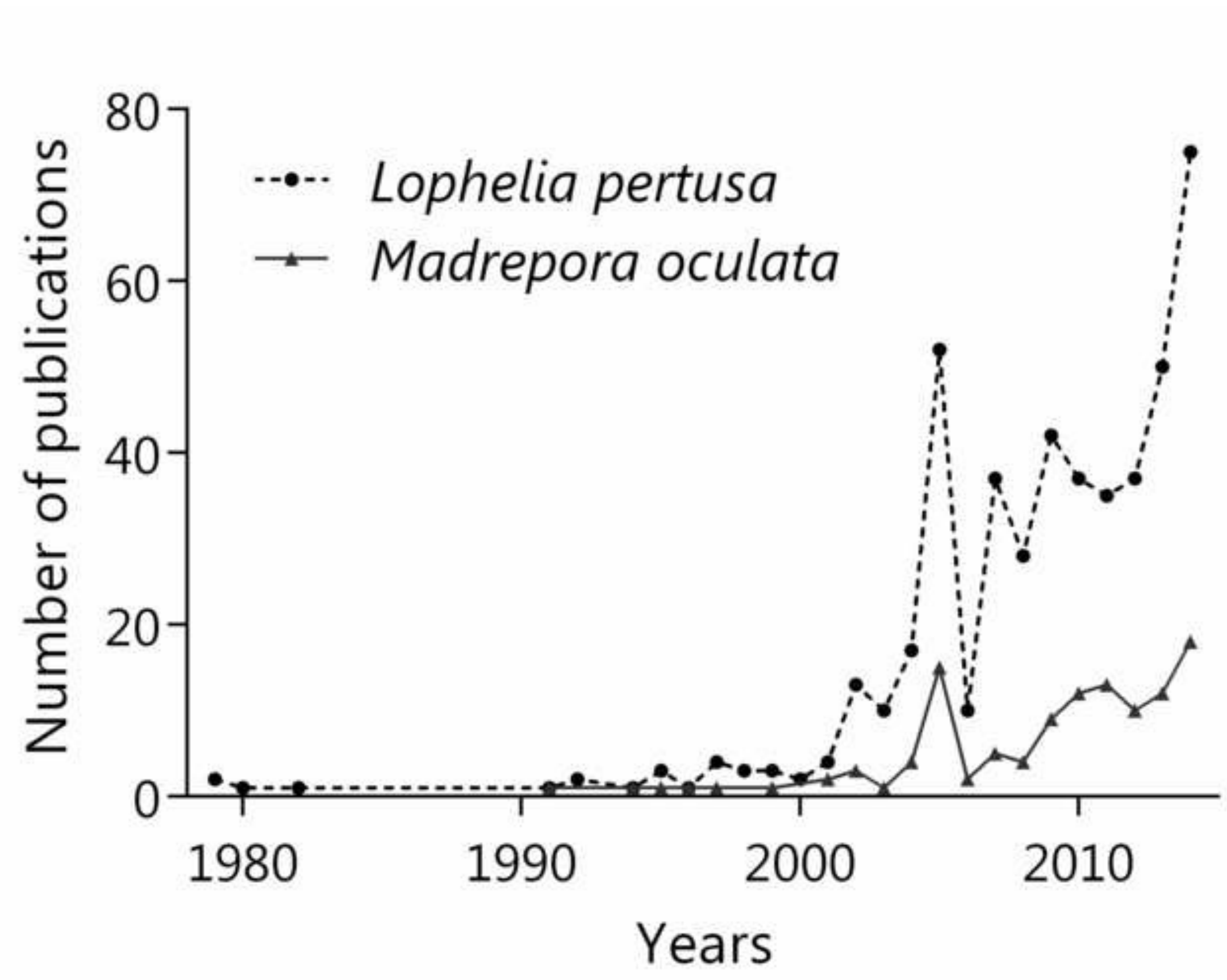




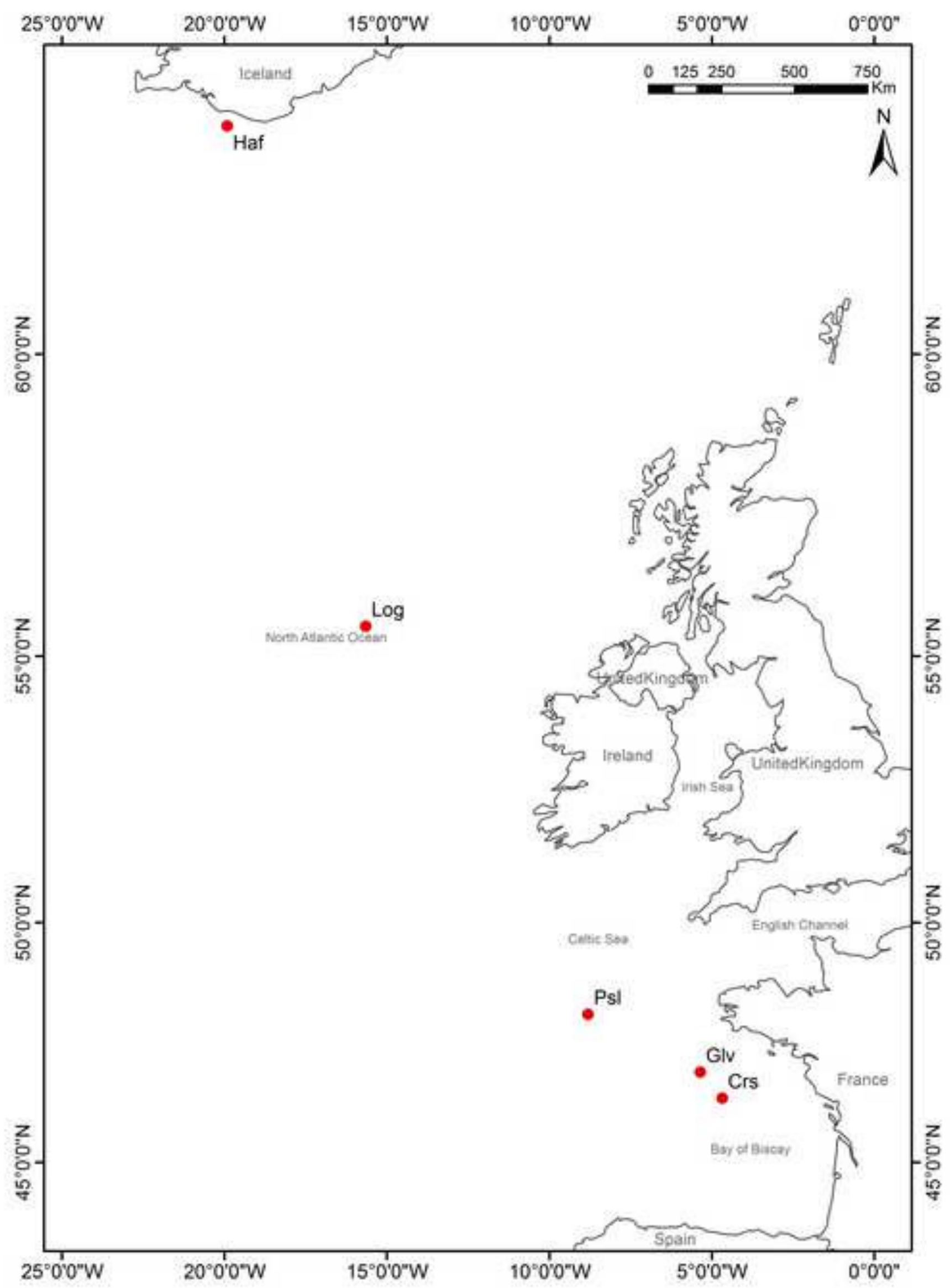



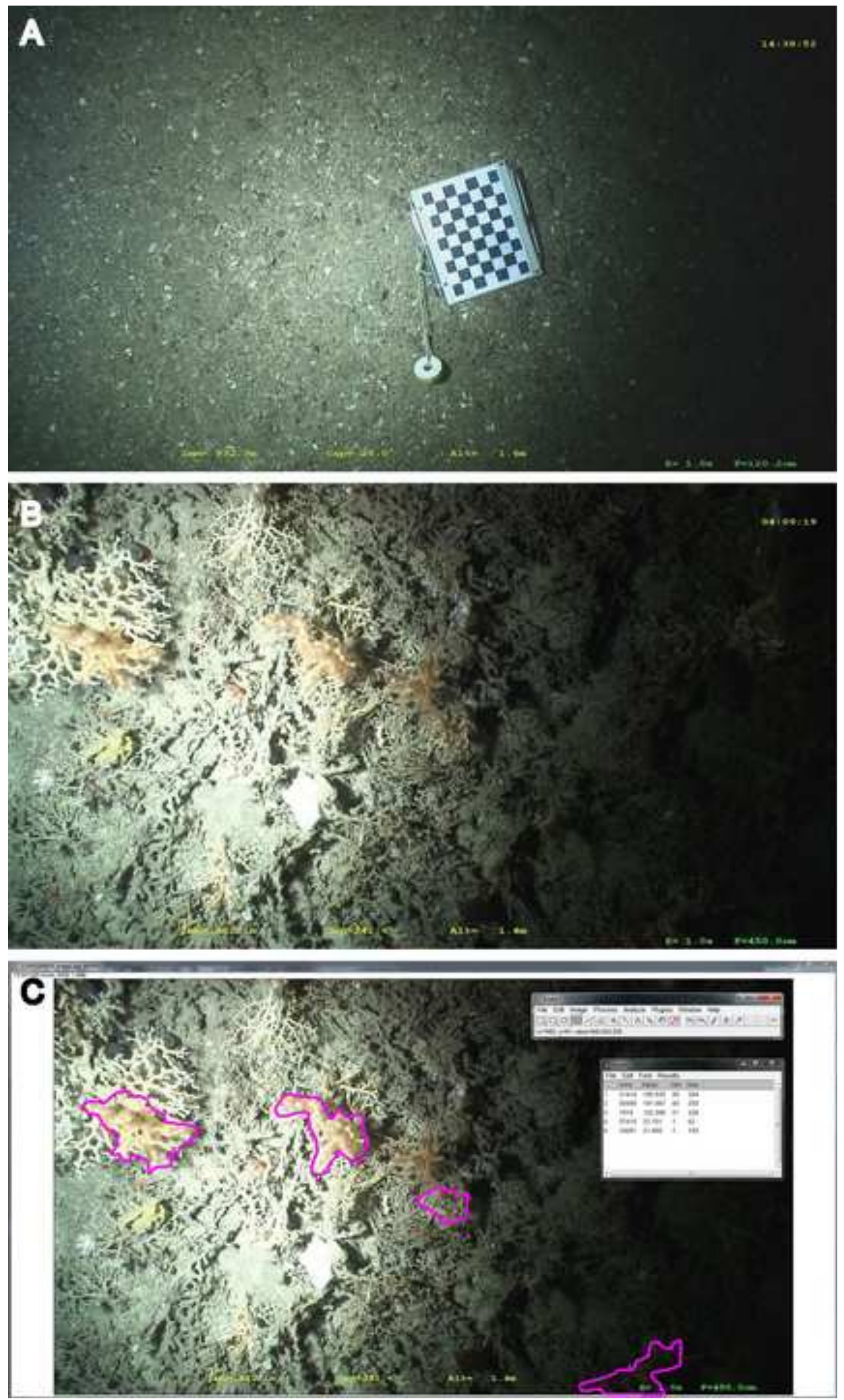
a)

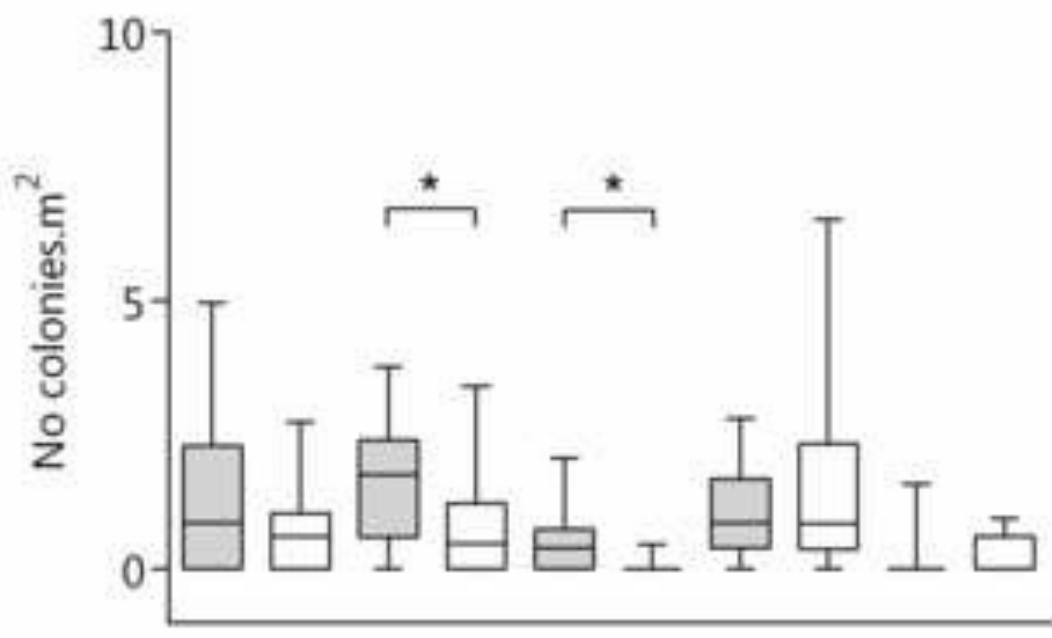

b)

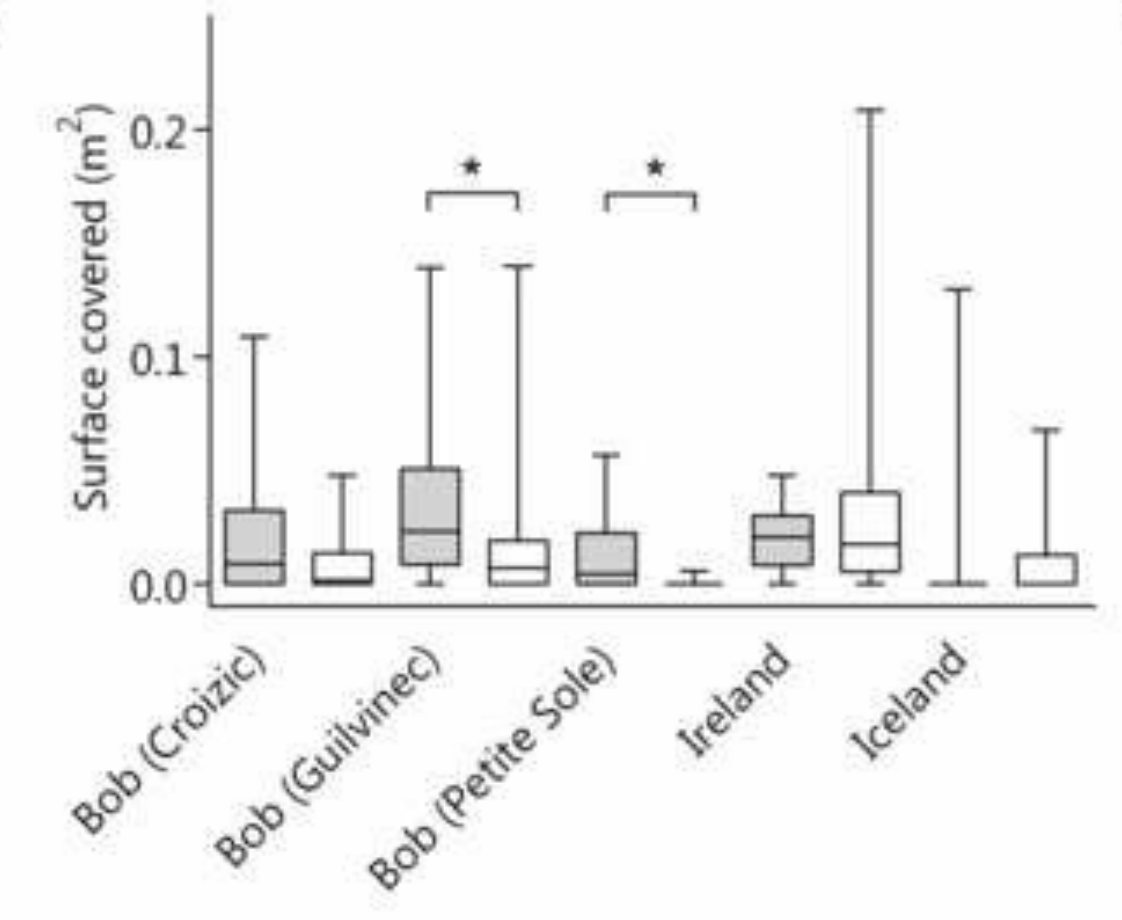

b)

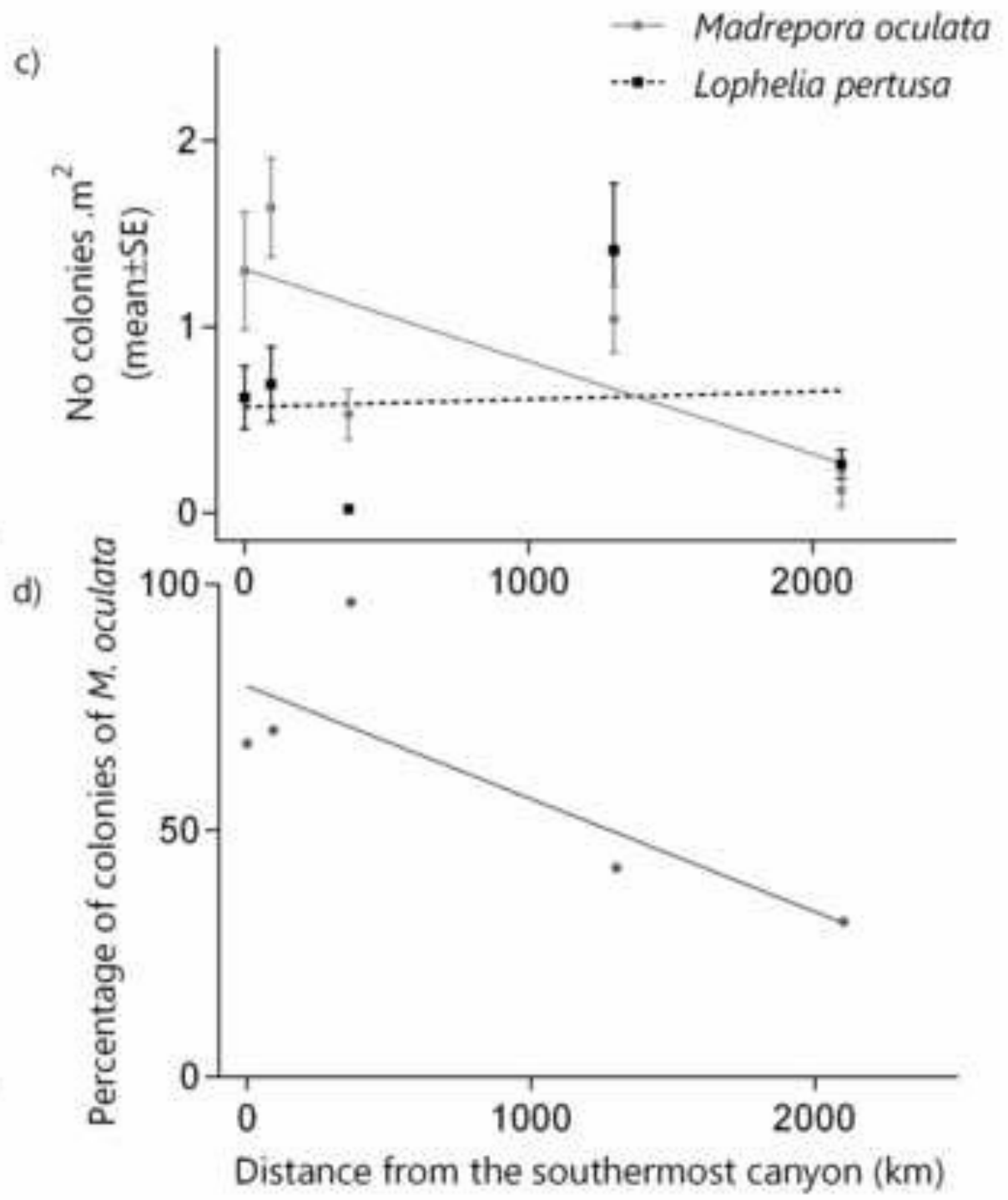

d)

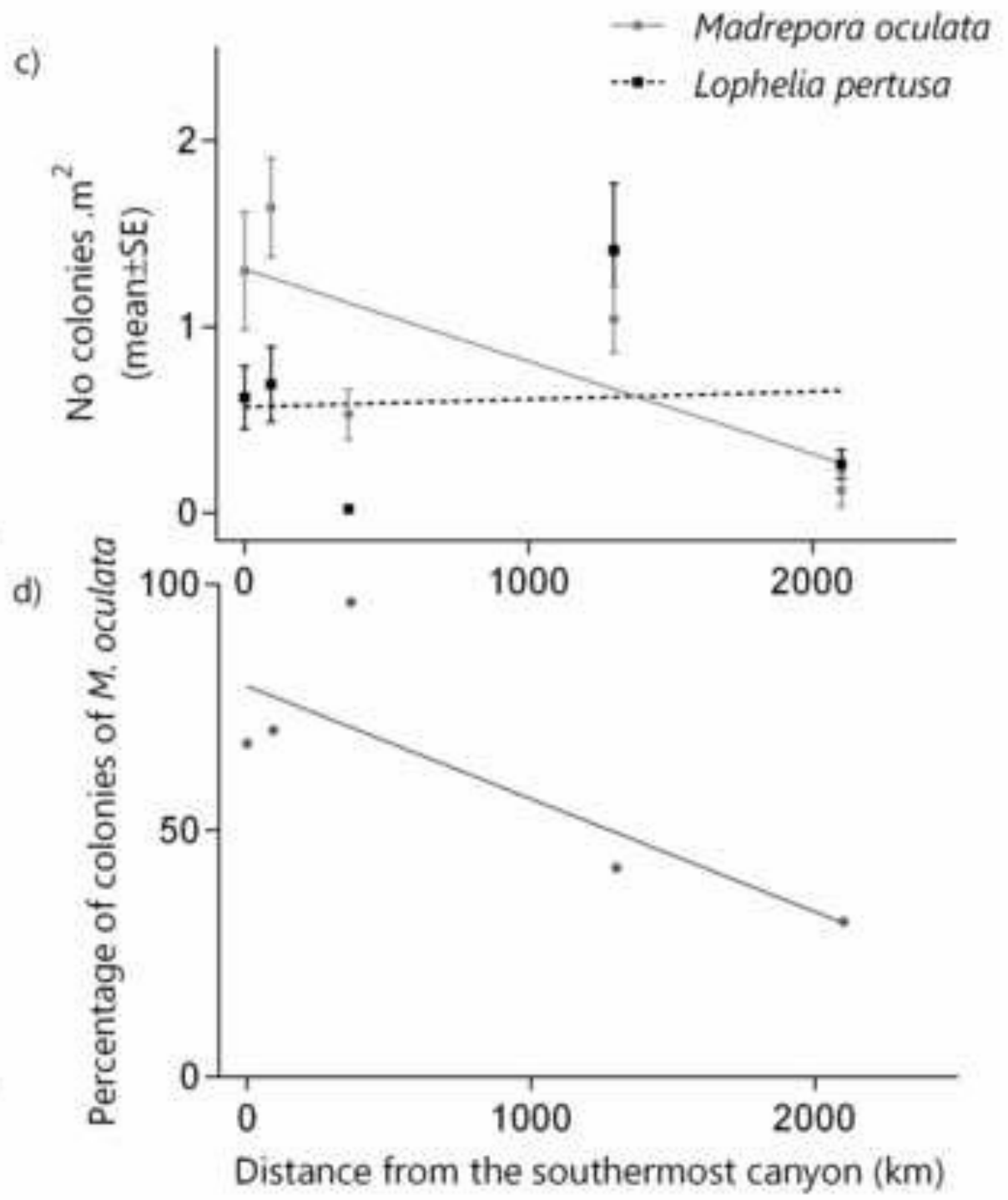

